\title{
Mercosur: ambitious policies, poor practices
}

\author{
Mercosul: políticas ambiciosas e práticas ruins
}

ANDRÉ FILIPE ZAGO DE AZEVEDO*,**+

RESUMO: O Mercosul alcançou importantes avanços, como a remoção de barreiras tarifárias e não-tarifárias intrabloco e o estabelecimento de uma tarifa externa comum para a maioria dos produtos. No entanto, seus planos ambiciosos de aprofundar o processo de integração que compreende a harmonização de políticas em areas como política de concorrência, compras governamentais, barreiras técnicas e medidas fitossanitárias ainda não foram implementados. Este artigo examina as políticas do Mercosul em relação às tarifas e outras barreiras não-tarifárias comparando-as com sua implementação, a fim de examinar até que ponto as propostas foram realmente cumpridas.

PALAVRAS-CHAVE: Integração regional; política comercial; Mercosul.

ABSTRACT: Mercosur has achieved important advances like the removal of intra- bloc tariff and non-tariff barriers and the establishment of a common external tariff for most products. However, its ambitious plans to deepen the integration process comprising harmonisation of policies in areas like competition policy, government procurement, technical barriers and phytosanitary measures have not been implemented yet. This paper examines Mercosur policies in relation to tariffs and other non-tariff barriers comparing them with their implementation, in order to examine the extent to which the proposals have actually been fulfilled.

KEYWORDS: Regional integration; trade policy; Mercosur.

JEL Classification: F13; F15.

\section{INTRODUCTION}

One of the most prominent features of the last decade has been the revival of regional agreements, a phenomenon that has been recognised as the second wave

\footnotetext{
*Professor da Universidade do Vale do Rio dos Sinos - UNISINOS, São Leopoldo/RS, Brasil. E-mail: azevedo@mercado.unisinos.br. Submitted: March 2003; accepted: November 2003.

* This paper heavily relies on chapter 2 of my thesis submitted for the degree of $\mathrm{PhD}$ at University of Sussex. I would like to thank the Brazilian Federal Agency for Post-Graduate Education (CAPES) for the financial support. I am also grateful to Aki Kuwahara from UNCTAD for providing data and to Alan Winters, Peter Holmes, Edmund Fitzgerald and Jim Rollo for comments and suggestions.
} 
of regionalism in contrast to the first wave that took place in the late 1950s and 1960s. ${ }^{1}$ Mercosur (Southern Common Market) formation coincides with the 'boom' of the new generation of Preferential Trade Agreements (PTAs). Created in March 1991 by the treaty of Asuncion, its ultimate goal is to form a common market among its bloc members by 2006. According to the bloc legislation, all internal trade should be duty-free and the national tariffs applied on third country imports should gradually converge to the CET without exceptions by then. Contingent protection in intra-bloc trade would be eliminated and all Mercosur members would follow a common external policy towards non-member countries. Technical and phytosanitary barriers would be harmonised and common competition and government procurement policies should be attained as well. The treaty of Asuncion also provided for free circulation of capital, services and people.

However, despite those typical features of the "new wave" of regionalism the bloc has allowed a wide range of exemptions and escape clauses from the rules. Moreover, the long history of failed regional agreements in South America and some developments in the integration process have raised some doubts about the capacity of bloc members to accomplish their ambitious intentions by 2006 . Hence what are the bloc holes and loopholes? ${ }^{2}$ And to what extent have the measures agreed been effectively implemented? This paper seeks to answer these questions in relation to border and contingent measures, also addressing the new regionalism issues which seek to deepen the scope of integration. The analysis will cover the transition phase (1991-94), when the intra-bloc tariff preferences were completed for most products, and the post-transition period (1995-2001), associated with the introduction of a Common External Tariff (CET) and the deepening measures sought by the bloc. This paper is divided into four sections, excluding this introduction. Sections 2, 3 and 4 present the bloc policies and identify the holes and loopholes related to tariffs, contingent protection and deeper integration, respectively. The last section offers some concluding remarks.

\section{TARIFFS}

\subsection{Intra-Bloc Tariffs}

Annex 1 of the treaty of Asuncion laid down the intra-bloc tariff reduction programme that took place during the transition period. It established the timeta-

\footnotetext{
${ }^{1}$ See Lawrence (1997) and Ethier (1998) for a description of the differences between the two waves of regionalism.

${ }^{2}$ Those expressions assume the meaning provided by Hoekman and Leidy (1993), where a hole constitutes a sectoral exclusion or exception from the agreement and loopholes consist of escape clauses, safeguard provisions and allowances for using discretionary measures to set and enforce standards and other NTBs.
} 
ble to eliminate "gradually, linearly and automatically" the internal tariffs from June 30, 1991 to December 31, 1994, being the preferences applied to the most favourable duties in force. As a first step bloc members conceded $47 \%$ intra-bloc preferences, which were steadily increased by 7 percentage points per semester until June 30, 1994, and finally reached $100 \%$ on December 31, 1994 (table 1). ${ }^{3}$ However, in order to minimise the costs of adjustment for those sectors more sensitive to competition within the bloc, the "Adjustment List" was created, which maintained in intra-bloc trade the same import tariff applied on third countries. This list, which constituted the bloc main hole during the transition period as far as tariffs are concerned, consisted of 394 items for Argentina, 324 for Brazil, 439 for Paraguay and 960 for Uruguay. ${ }^{4}$ These exemptions from intra-bloc duty-free would be reduced at the end of each calendar year. ${ }^{5}$

\begin{tabular}{cccccccc}
\hline \multicolumn{7}{c}{ Table 1: Tariff Reduction in Intra-Mercosur Trade (\%) } \\
\hline \multicolumn{7}{c}{1991} & \multicolumn{2}{c}{1992} & \multicolumn{2}{c}{1993} & \multicolumn{2}{c}{1994} \\
\hline 30 June & 31 Dec & 30 June & 31 Dec & 30 June & 31 Dec & 30 June & 31 Dec \\
47 & 54 & 61 & 68 & 75 & 82 & 89 & 100 \\
\hline
\end{tabular}

Source: Treaty of Asuncion - Annex 1.

By the end of the transition period Mercosur was expected to become a customs union, with internal free trade and a common CET comprising all goods according to the treaty of Asuncion provisions. However, it did not happen according to the schedule laid down since an extended period of protection in intra-bloc trade was granted to those most sensitive sectors, representing the first major blow to the original plans. Firstly, bloc members created the "Final Adjustment List" that came into effect from January 01, 1995, which extended the internal protection of those products that were either already included in the previous "Adjustment List" or the target of a safeguard measure in intra-bloc trade during the transition period. ${ }^{6}$

The tariffs would converge to zero according to a linear and automatic reduction, coming down by $25 \%$ each year. ${ }^{7}$ The final deadline for the tariffs of these products to converge to zero was January 01, 1999 in Argentina and Brazil, and

\footnotetext{
${ }^{3}$ During the transition period Mercosur members were allowed to modify unilaterally their Most Favoured

${ }^{4}$ The article 6 of treaty of Asuncion laid down the list of products belonging to the "Adjustment List".

${ }^{5}$ For Argentina and Brazil the tariffs would be phased out from December 31, 1990 to December 31, 1994 by $20 \%$ per year. For Paraguay and Uruguay they would go down initially by $10 \%$ when the treaty came into force and on December 31, 1991, and by 20\% on December 31 of the next four years from 1992 to 1995.

${ }^{6}$ Decision $\mathrm{N}^{\mathrm{o}}$ 05/94.

${ }^{7}$ The ultimate condition was that the intra-bloc tariff would never be superior to the CET (Resolution $\left.\mathrm{N}^{\circ} 48 / 94\right)$.
} 
January 01, 2000 in Paraguay and Uruguay. In 1995 this list comprised 29 products at HS 08-digit level in Brazil, 212 in Argentina, 432 in Paraguay and 958 in Uruguay.

Besides the "Final Adjustment List" another hole in the bloc agreement in force after the end of the transition period refers to the so-called special concessionary regimes, which comprise those products originating in free trade zones, export processing zones and special customs areas. ${ }^{8}$ They should pay in intra-bloc trade either the CET or the national tariff whenever they belong to the exception list to the CET. The intra-bloc trade for those products would be freed only on January $01,2006 .^{9}$ Moreover, until December 31,2000 , duties on intra-bloc trade would be imposed on products contained in the exception list to the CET that were not considered as originating in the bloc according to the bloc rules of origin. However, the most prominent cases involving products transitionally excluded from the internal liberalisation programme comprise the automotive regime and sugar, which were scheduled to have the tariff eliminated by January 2000 and January 2001, respectively. The automotive agreement created a managed trade system between Mercosur members based on minimum regional contents (60\%), export balancing requirements and concessional entry. ${ }^{10}$ As far as the requirements were fulfilled the intra-bloc trade would be duty-free in vehicles and parts (IDB, 1996), creating the conditions that led to an impressive increase in intra-bloc trade. However, the regional content and the export balancing requirements are incompatible with the WTO Agreement on Trade Related Investment Measures (TRIMS) and were to be eliminated by the end of 1999. In relation to sugar, provisions established a transition period until January 01, 2001, in which a gradual liberalisation of intra-bloc trade would take place, accompanied by measures to eliminate government policies that distorted the production and exports of sugar. ${ }^{11}$

The foregoing analysis shows that most of the main departures from intra-bloc free trade were to be eliminated by the beginning of the year 2001. However, the rules were only respected in one case, the "Final Adjustment List", while in the remaining cases the pre-established agreements were not implemented, being continually postponed. As regards the products in the exception list rejected by the rules of origin, the latest developments show that its removal seems unlikely to occur before 2006 when the restrictions on the special concessionary regimes would also be eliminated. ${ }^{12}$ Although at the end of 1999 a new automotive agreement was attained it was not implemented. In May 2000, members of Mercosur decided to pro-

\footnotetext{
${ }^{8}$ Decision $\mathrm{N}^{\mathrm{o}}$ 08/94.

${ }^{9}$ Decision $\mathrm{N}^{\circ} 31 / 2000$.

${ }^{10}$ Decision $N^{\circ} 29 / 94$.

${ }^{11}$ Decision $N^{\circ} 19 / 94$.

${ }^{12}$ Decision $N^{\circ} 21 / 98$.
} 
long the managed trade in this sector until 2006, despite the initial intention to liberalise trade in this sector in 2000. Finally, the gradual liberalisation on intra-bloc trade of sugar also did not take place since bloc members did not agree about the character of the national distortions leaving the tariff in place even after the deadline for its elimination. ${ }^{13}$ Hence, most of the remaining barriers on intra-bloc trade in force just after the end of the transition period in 1995 were extended until January 2006 violating the original rules.

The strategy followed by Mercosur members to initially remove the intra-bloc barriers in sectors without a major potential for trade conflicts and to postpone the liberalisation in the most sensitive products reflects what Preusse (2001) defines as "selective problem solving". However, this could lead to a trap in which the pressure groups that benefited from the remaining barriers in intra-bloc trade could try to perpetuate this situation. The continuous delays in implementing the rules agreed in those "problematic" sectors in Mercosur are signalling this. Moreover, according to Grossman and Helpman (1995) the exceptions from intra-bloc trade are more likely to occur in sectors prone to trade creation since the political cost of trade diversion is higher than the political cost of trade creation in the importing country while the political gains are higher in the case of trade diversion compared with trade creation for the exporting country. Olarreaga and Soloaga (1998) using a model to explain the deviations from internal trade based on the political structure of each Mercosur member, confirm the Grossman and Helpman view that those sectors with more tendency to trade creation tend to be exempted from internal free trade as far as tariffs are concerned. Given this evidence it seems that the bloc is still far away from exploiting all the trade potential it would obtain from a complete elimination of intra-bloc tariffs.

\subsection{The Common External Tariff}

As planned in the treaty of Asuncion the customs union was launched on January 01, 1995, when the CET came into force. The CET was structured into eleven tariff levels with two-percentage point interval ranging from zero to $20 \%$, with the unweighted average of $11.2 \%$. It is based on the newly created Mercosur Common Nomenclature (MCN), which has the first 06-digits from the Harmonised Commodity Classification and Coding System (HS), while the seventh and eighth digits were created according to a definition set up by bloc members. The most protected sectors, as can be seen in table 2, were arms \& ammunition $(20.0 \%)$, footwear $(19.1 \%)$, textiles $(17.3 \%)$, prepared food $(14.9 \%)$, and transport equipment $(14.8 \%)$, while the most liberal were mineral products $(2.4 \%)$, works of art $(4.0 \%)$, wood $(6.9 \%)$ and chemicals $(7.6 \%)$. Recent evidence shows that although both po-

\footnotetext{
${ }^{13}$ Argentina has demonstrated a lack of disposition to abolish the tariffs on Brazil's exports of sugar arguing that Brazil's subsidies conceded to production of alcohol remain in force.
} 
litical economy forces and terms of trade effects are responsible for the final configuration of Mercosur CET, the former seems to explain a larger proportion of the CET (Olarreaga et al., 1999).

Although the CET was negotiated for all products, not all converged immediately to the CET in January 1995, with the bloc legislation providing many holes. The first hole comprised capital goods, information technology and telecommunications equipment. ${ }^{14}$ For capital goods, Argentina and Brazil would converge to the scheduled CET of $14 \%$ on January 01,2001 , while for Paraguay and Uruguay the period was extended to January 01,2006 . In the case of information technology and telecommunications equipment the CET of $16 \%$ would be attained on January 01,2006 , for all members. ${ }^{15}$ Sugar and automotive products were also targets for special regimes, as occurred with intra-bloc trade, and would conform to the common regime only by January 01,2001 , and January 01,2000 , respectively, being subject to national tariffs until then. Those products belonging to the special concessionary regimes constitute another exemption from the CET, since they received a differentiated treatment in each member state. Apart from those sectors already mentioned, each member of the bloc could maintain a list of up to 300 exceptions from the CET (399 in the case of Paraguay), which could be higher or lower than the CET, until January 01, 2001 (January 01, 2006 for Paraguay). ${ }^{16}$ Another departure from the CET was allowed in order to guarantee a normal and continuous supply of products in cases of shortage and was initially scheduled to last until April 28, 1996. ${ }^{17}$ The products in the "Final Adjustment List" and those included in bilateral negotiations with other Latin American Integration Association (LAIA) members were also permitted to present a different tariff level in each member for a longer period until the end of 1999 and 1995, respectively.

Those many departures from the CET led to a significant number of non-uniform tariff lines between Mercosur members. The proliferation of holes in the CET has undermined two of the main advantages of a customs union when compared with a free trade area: the absence of a need for rules of origin to deter trade deflection in intra-bloc trade, and the security of access to those markets. The latter is quite important in the case of Mercosur since tariff bindings of all bloc members under the WTO provisions are higher than the MFN applied rates. ${ }^{18}$ Thus, the CET,

\footnotetext{
${ }^{14}$ Decision $N^{\circ} 07 / 94$.

${ }^{15}$ Pereira (1999) illustrates the conflict of interests between Argentina and Brazil regarding these sectors that led to the delay in implementing the CET. While Argentina sought to eliminate the tariffs, Brazil, as the major producer of these items, tried to keep the tariffs in place.

${ }^{16}$ In fact, all members included fewer products in this list than was allowed. Argentina included 231 products at HS 08-digit level, while Brazil, Paraguay and Uruguay included 171, 214 and 212, respectively.

${ }^{17}$ Resolution N $N^{\circ}$ 22/95. Afterwards, Resolution No 33/98 extended its duration until December 31, 2000.

${ }^{18}$ Tariff bindings for Mercosur countries after the WTO's Uruguay Round are usually at a ceiling rate
} 
even when it represents an increase in the previous national applied rates, would be a guarantee that members of the bloc would not increase their national tariffs to match their binding upper-limits at the WTO. ${ }^{19}$

However, the administration of the CET has also been quite different from what was originally established by the norms of the bloc. Even the existence of many exemptions was not sufficient to avoid more changes in the CET after the end of the transition period. Three cases deserve to be stressed. Firstly, in March 1995, the bloc conceded Brazil the right to change the CET on up to 150 tariff lines for one year so as to guarantee the success of its stabilisation plan, menaced by the Mexican crisis. ${ }^{20}$ In order to avoid trade distortions, all other bloc members were also allowed to adopt the same tariff level set by Brazil. As a result, both Brazil and Argentina raised import tariffs on a wide variety of products with the former in creasing tariffs of many consumption goods, such as cars, toys and footwear to the ceiling rate of $35 \%$ bound at the WTO, while Argentina focused on capital and telecommunication goods. Thus, after only a few months the expected role of the CET securing access to the bloc market at lower levels than the WTO bindings was completely undermined. Secondly, in November 1997, as a result of the international turbulence that followed the Asian financial crisis, the CET rules were changed once more. All Mercosur members agreed to raise temporarily the CET, by 3 percentage points, which was scheduled to be in force from January 01, 1998 to December 31, 2000..$^{21}$ Thirdly, in April 2001, Argentina was allowed to remove some consumption and capital goods from the CET until December 31,2002 , increasing the tariffs to $35 \%$ in the former and reducing the tariffs to zero in the latter. ${ }^{22}$

The impact of such measures was reflected in the average MFN tariff of each member of the bloc. Looking at Mercosur members' average MFN tariff at HS-06 digit level, it is possible to identify precisely four different periods in the 1990s (table 3). During the transition period, while most countries were still involved in unilateral tariff reduction, the average MFN tariff went down significantly in all countries, especially in Brazil. ${ }^{23}$ However, in 1995 when the CET was introduced and new ex-

of $35 \%$ for manufactures and 55\% for agricultural products (WTO Trade Policy Review, 1996, 1997, 1998a, 1998b).

${ }^{19}$ Applied tariffs, at the time of the end of the Uruguay Round, were significantly lower than tariff bounds due to unilateral trade liberalisation undertaken by Mercosul members between the late 1980s and early 1990s.

${ }^{20}$ Decision $\mathrm{N}^{\circ} 07 / 95$.

${ }^{21}$ Decision $\mathrm{N}^{\circ} 15 / 97$. Uruguay and Paraguay, however, were against the wide scope of this measure, and applied it only selectively.

${ }^{22}$ Decision $N^{\circ} 01 / 2001$.

${ }^{23}$ Tariff data information for Uruguay in 1994 was not available at UNCTAD database but WTO Trade Policy Reviews suggest that they followed the same pattern of the other Mercosur members. 
Table 2: Mercosur CET at HS 08-digit level (1995)

\begin{tabular}{|c|c|c|c|c|c|c|c|}
\hline $\begin{array}{c}\text { HS } \\
\text { Section }\end{array}$ & Description & $\begin{array}{c}\mathrm{N}^{\circ} \text { of } \\
\text { Tariff Lines }\end{array}$ & $\begin{array}{c}\text { Simple } \\
\text { Average }\end{array}$ & $\begin{array}{l}\text { Std. } \\
\text { Dev. }\end{array}$ & Mode & Max. & Min. \\
\hline $01-05$ & Live animals \& products & 252 & 9.1 & 4.0 & 10.0 & 16.0 & 0.0 \\
\hline 06-14 & Vegetable products & 355 & 7.7 & 3.9 & 10.0 & 14.0 & 0.0 \\
\hline $15-15$ & Fats and oils & 77 & 8.5 & 3.6 & 10.0 & 12.0 & 2.0 \\
\hline $16-24$ & Prepared food & 255 & 14.9 & 3.9 & 16.0 & 20.0 & 6.0 \\
\hline $25-27$ & Mineral products & 211 & 2.4 & 1.8 & 4.0 & 6.0 & 0.0 \\
\hline $28-38$ & Chemical \& products & 2,587 & 7.6 & 5.5 & 2.0 & 18.0 & 0.0 \\
\hline $39-40$ & Plastics \& rubber & 356 & 12.2 & 5.4 & 14.0 & 18.0 & 0.0 \\
\hline $41-43$ & Hides and skins & 108 & 10.9 & 6.5 & 10.0 & 20.0 & 2.0 \\
\hline $44-46$ & Wood and articles & 120 & 6.9 & 3.9 & 10.0 & 14.0 & 2.0 \\
\hline $47-49$ & Pulp, paper etc & 159 & 12.1 & 4.5 & 12.0 & 16.0 & 0.0 \\
\hline $50-63$ & Textile \& articles & 916 & 17.3 & 3.4 & 18.0 & 20.0 & 2.0 \\
\hline $64-67$ & Footwear, headgear & 62 & 19.1 & 1.4 & 20.0 & 20.0 & 16.0 \\
\hline $68-70$ & Articles of stone & 199 & 11.3 & 4.0 & 10.0 & 20.0 & 0.0 \\
\hline $71-71$ & Precious stones, etc & 58 & 10.2 & 6.0 & 18.0 & 18.0 & 0.0 \\
\hline $72-83$ & Base metals \& products & 715 & 12.5 & 4.5 & 12.0 & 20.0 & 0.0 \\
\hline $84-85$ & Machinery & 1,584 & 12.6 & 5.8 & 14.0 & 20.0 & 0.0 \\
\hline $86-89$ & Transport Equipment & 197 & 14.8 & 6.2 & 14.0 & 20.0 & 0.0 \\
\hline $90-92$ & Precision Instruments & 442 & 13.6 & 6.0 & 14.0 & 20.0 & 0.0 \\
\hline $93-93$ & Arms and Ammunition & 18 & 20.0 & 0.0 & 20.0 & 20.0 & 20.0 \\
\hline $94-96$ & Miscellaneous & 159 & 18.5 & 1.2 & 18.0 & 20.00 & 14.0 \\
\hline \multirow[t]{2}{*}{$97-99$} & Works of Art & 7 & 4.0 & 0.0 & 4.0 & 4.0 & 4.0 \\
\hline & Average & & 11.2 & 6.2 & 14.0 & 0.0 & 20.0 \\
\hline
\end{tabular}

Source: author's calculations based on Comtrade - UNCTAD.

emptions from the CET were allowed, the average MFN tariff reversed the previous trend and went up compared to 1994. From 1995 to 1997, the average MFN tariff remained stable as no major changes in CET were registered. Finally, the average MFN tariff increased again in 1998 due to the 3-percentage rise in the CET in December 1997. As a result, in all members of the bloc the average MFN tariff was higher in 1998 than its level in the last year of the transition period. In the case of Argentina, the average MFN tariff in 1998 was even higher than it was in 1992 at the beginning of the bloc formation. Hence, since the end of the transition period there has been an increase in the degree of discrimination against third countries, undermining the expected role of the CET as a guarantee that it would secure the tariffs of Mercosur members well below their WTO bound rates. 
Table 3: MFN tariffs at HS 06-digit level by Mercosur member, 1991-98 (\%)

\begin{tabular}{cccccccc}
\hline Country & Measure & $1991 \mathrm{a}$ & 1994 & 1995 & 1996 & 1997 & 1998 \\
\hline \multirow{3}{*}{ Argentina } & Simple Average & 12.63 & 9.87 & 12.10 & 12.76 & 12.86 & 15.28 \\
& Peaks & 35.00 & 20.00 & 29.00 & 30.00 & 30.00 & 33.00 \\
& Lows & 0.00 & 0.00 & 0.00 & 0.00 & 0.00 & 0.00 \\
\hline \multirow{3}{*}{ Brazil } & Simple Average & 26.10 & 12.82 & 13.05 & 13.39 & 13.11 & 15.94 \\
& Peaks & 85.00 & 40.00 & 32.00 & 70.00 & 63.00 & 49.00 \\
& Lows & 0.00 & 0.00 & 0.00 & 0.00 & 0.00 & 0.00 \\
\hline \multirow{3}{*}{ Paraguay } & Simple Average & 15.53 & 7.90 & 10.74 & 10.98 & 11.08 & 11.14 \\
& Peaks & 72.00 & 32.00 & 20.00 & 30.00 & 25.00 & 30.00 \\
& Lows & 0.00 & 0.00 & 0.00 & 0.00 & 0.00 & 0.00 \\
\hline \multirow{2}{*}{ Uruguay } & Simple Average & 16.58 & n.a & 10.91 & 11.31 & 11.43 & 13.70 \\
& Peaks & 24.00 & n.a & 32.00 & 30.00 & 27.00 & 24.00 \\
\hline & Lows & 10.00 & n.a & 0.00 & 0.00 & 0.00 & 0.00 \\
\hline
\end{tabular}

a. 1992 for Argentina and Uruguay.

Source: author's calculations based on UNCTAD database.

Beside the rise in the average MFN tariff, most products showed an increase in their tariff levels after 1994 as well. Table 4 compares the share of MFN tariffs at HS 06 digit level that went up or down in each of the bloc members in four critical periods of the bloc formation, the first and last year of the transition period,

1991 and 1994, respectively, the first year of incomplete customs union (1995), and the year immediately after the 3-percentage increase in the CET (1998). In 1995 more tariffs increased than decreased in every single member compared to 1994, reaching a peak in Argentina, where $64.5 \%$ of tariff lines rose. The reverse situation was observed during the transition period, when the majority of products in all Mercosur members had their tariffs reduced. In the case of Brazil, only $0.6 \%$ of the tariff lines went up, while $83.8 \%$ came down during this period. From 1994 to

1998 in all countries the share of tariff lines that moved up exceeded $60 \%$. Argentina symbolises what occurred in this period where for each tariff that declined almost eleven went up. As regards the whole period from 1991 to 1998, in Argentina, where the unilateral tariff reduction was almost completed by 1992, most tariffs rose, while in Brazil and Paraguay, where the unilateral trade liberalisation coincided with the transition period, the tariffs of most products declined. These results, based on either the average or the number of MFN tariffs at HS 06 digit level, suggest that the decline in tariffs during the transition period occurred despite Mercosur, as each member of the bloc still had autonomy of its own tariffs, but they increased from 1995 onwards partially because of it, as the CET was implemented. 
Table 4: Change in MFN tariff lines at HS 06-digit level by Mercosur member, 1991-98 (\%)

\begin{tabular}{ccccc}
\hline Countries & Argentinaa & Brazil & Paraguay & Uruguayb \\
\hline $1991<1994$ & 22.0 & 0.8 & 6.9 & - \\
$1991>1994$ & 64.9 & 83.8 & 86.6 & - \\
$1994<1995$ & 64.5 & 34.7 & 62.1 & - \\
$1994>1995$ & 18.3 & 24.7 & 27.5 & - \\
$1994<1998$ & 88.3 & 78.9 & 62.6 & 92.7 \\
$1994>1998$ & 7.9 & 11.6 & 26.1 & 3.6 \\
$1991<1998$ & 64.1 & 19.0 & 33.0 & 83.0 \\
$1991>1998$ & 27.5 & 78.5 & 60.4 & 15.0 \\
\hline
\end{tabular}

a: 1992 instead of 1991 for Argentina.

b: 1992 instead of 1991 and 1995 instead of 1994 for Uruguay. Source: author's calculations based on UNCTAD database.

One of the major problems stemming from the proliferation of products exempted from the CET is that the need for rules of origin spread to a large number of products. Originally only three groups of products would be subject to rules of origin in intra-bloc trade. ${ }^{24}$ First, those products in a process of convergence to the CET. Second, those products that were subject to the CET but whose inputs were both in process of convergence to the CET and represent more than $40 \%$ of the fob value of the final product. Third, those products subject to different commercial policies. To be considered Mercosur-originated, a product should have a bloc content of at least $60 \%$ and the transformation process undertaken within the bloc using inputs imported from third countries should result in a change in the bloc's classification in relation to those inputs. The abolition of rules of origin for those products would be gradual according to the schedule to eliminate the differences in commercial policies of bloc members and should be completed by January 2006. However, due to the proliferation of the exceptions from the CET all products were still subject to rules of origin in intra-regional trade up to December 31, 2000.25 Thus, despite its original plans to become a common market, the bloc is still facing a problem identified by Krueger (1997) as typical of a free trade area, with all products subject to rules of origin examination.

However, as most products excluded from the CET were to converge to it by end 2000, the foregoing problems would then be alleviated until the bloc finally achieves the customs union status in 2006. Nevertheless, as had already occurred in other occasions, the plans were not fully accomplished since the majority of holes

\footnotetext{
${ }^{24}$ Decision $N^{\circ}$ 06/94.

${ }^{25}$ Decision $\mathrm{N}^{\circ} 21 / 98$.
} 
were continued to the end of 2005. Sugar and products of the automotive regime started 2001 without definition of a new policy. The automotive regime, though had been reformulated with minor changes from the previous one, was not implemented because of a different interpretation between Argentina and Brazil about the formula to calculate the $60 \%$ bloc content. ${ }^{26}$ While the removal of capital goods from the exception list of Argentina and Brazil also did not take place and a decision was delayed until the end of 2001, the 300 products in the exception list were reduced to 100 and would be in force until 2006. ${ }^{27}$ Moreover, the supply shortage list was also extended indefinitely as the members of the bloc were allowed to keep using this instrument in 2001, and the maintenance of special concessionary regimes until 2006 forced the exemptions from the CET to remain in force until then. ${ }^{28}$ Finally, the allowance for keeping the bilateral agreements preferences with the Andean Pact and Mexico impeded the removal of the exemption caused by different commercial policies. Thus, the only hole from the CET that was actually removed as scheduled was that linked to products in the "Final Adjustment List", which was abolished by all Mercosur members by end 1999 .

In summary, the large number of exceptions from the CET initially allowed, the proliferation of new exceptions after the transition period, and the delays to eliminate original exceptions to the CET created a lack of predictability in the future of the rules of the game which undermined the prospects for both trade and investments in the bloc. The rise in the external tariffs of bloc members, due to both the three-percentage increase in the CET in 1997 and the increase in most of national tariffs exempted from the CET, also indicates a reversal in the unilateral trade liberalisation initiated in the mid-1980s in all Mercosur members. These facts suggest that the pressure groups that were able to influence the configuration of the CET, especially in Brazil, have also been capable of shaping its developments after wards. This is in line with Bhagwati's (1993) "these are our markets syndrome" argument, which establishes that in a setting where producers have an important role in determining trade policies the bloc formation could led to increased protection against non-members of the bloc.

\section{CONTINGENT PROTECTION}

The presence of safeguards has been widely accepted as both an insurance mechanism and a safety valve in most PTAs. According to Hoekman and Kostecki (1995:161) "safeguard provisions are often critical to the existence and operation

\footnotetext{
${ }^{26}$ Decision $\mathrm{N}^{\mathrm{o}} 70 / 2000$.

${ }^{27}$ Decision $\mathrm{N}^{\mathrm{o}} 68 / 2000$.

${ }^{28}$ Decision $\mathrm{N}^{\circ} 69 / 2000$.
} 
of trade-liberalising agreements, as they function as both insurance mechanisms and safety-valves". The prohibition of any mechanism allowing national governments to temporarily withdraw their normal obligations under the agreement in exceptional circumstances would undermine the prospects for national governments to accept participation in the first place. However, recent research has showed that the presence of Antidumping (AD), Countervailing duties (CVDs) and safeguard provisions in a multilateral agreement — even when not exercised — may reduce competition between foreign exports and domestic import-competing firms, perhaps even eliminating the gains from partial tariff liberalisation (Hoekman and Leidy, 1993). The same rationale applies in the context of a preferential trade agreement since its objectives are usually more ambitious than multilateral liberalisation, implying a much deeper integration. Thus the allowance for many types of safeguard provisions in preferential agreements, such as anti-dumping and countervailing duties, could counteract or even completely undermine the effectiveness of intra-bloc tariff elimination.

In order to avoid the negative effects safeguards may cause, the treaty of Asuncion established conditions under which they may be imposed in internal trade during the transition period, in accordance with the procedures adopted by GATT-1947 provisions. Aware of the potential damage that safeguards could provoke within the bloc, the article 5 of the treaty of Asuncion expresses clearly that in 'no event may the application of safeguard clauses extend beyond 31 December 1994'. The only exemption was the "special concessionary regimes", where application of safeguards was still allowed..$^{29}$ During the transition period no provisions were established to address extra-bloc safeguards. This allowed Mercosur members to make use of their own legislation on this matter. Only in December 1996 was a set of measures put in place, when common safeguard legislation against third countries was laid down, in conformity with the WTO procedures in this area. ${ }^{30}$ That instrument allowed that a safeguard measure could be taken against third countries both in name of the bloc as a whole or on behalf of a single member.

Although safeguards on internal trade have been prohibited since the beginning of 1995 by the treaty of Asuncion, Mercosur members opted for allowing the incidence of anti-dumping measures in intra-bloc trade even beyond the transition period in order to "level the playing field". ${ }^{31}$ Therefore, the bloc imposed the condition of either eliminating domestic incentives or harmonising the bloc members'

\footnotetext{
${ }^{29}$ Decision $N^{\circ} 08 / 94$.

${ }^{30}$ Decision $\mathrm{N}^{\mathrm{o}} 17 / 96$.

31 There are many criticisms about the supposedly fair play caused by AD actions. Some believes they actually tilt the playing field (e.g. Hoekman and Kostecki, 1995) while others consider them as simple protectionism (e.g. Finger, 1993).
} 
competition rules in order to abolish AD actions in intra-bloc trade. ${ }^{32}$ This issue of conditioning the elimination of $\mathrm{AD}$ measures within the bloc to harmonisation or elimination of domestic incentives or distortions is controversial. While some argue in favour of common competition policies (e.g. Guasch and Rajapatirana, 1998) to 'level the playing field' in intra-bloc trade as a condition to removing the AD actions, others (e.g. Hoekman, 1998) reject this conditionality stressing that whatever the reason for supporting common competitive rules (fear of predation or foreign strategic policy) it is neither effective nor the best policy choice. However, as there have been no substantial advances in negotiations to eliminate or harmonise the subsidies granted by bloc members or to reach a common competition policy, Mercosur members have been continuously allowed to apply CVDs or AD measures in intra-regional trade since $1994 .{ }^{33}$

In spite of the potential to use $\mathrm{AD}$ measures to restrain imports from other bloc members, Brazil, Paraguay and Uruguay did not take contingent actions to protect their sensitive products from competition within the bloc between 1991 and 2000. In this period neither safeguard actions nor countervailing duties nor AD measures were imposed on imports from other bloc members. ${ }^{34}$ In contrast, antidumping did become the preferred instrument in Argentina to deter imports from within the bloc, especially from Brazil. What is most striking is the high incidence of these restrictions applied by Argentina on intra-regional trade when compared with third countries (table 5). Since 1991, 34\% of the AD actions initiated in Argentina related to intra-bloc imports. In the transition period alone, about half of the initiations had a member of the bloc, especially Brazil, as a target, declining slightly afterwards. ${ }^{35}$

Most of these initiations were transformed into either a provisional or a definitive measure in the following years. As a result, in every year of the 1990s more than a third of all AD measures in force in Argentina were applied on imports coming from other partners. As this represents a share higher than that of Argentina's intra-bloc imports in relation to total imports, there is evidence of a bias against imports from Mercosur partners. ${ }^{36}$

32 Despite all negotiations undertaken at the bloc level about competition policy, bloc members were still following their own legislation in this matter by end 2000 .

${ }^{33}$ Decision 27/00 conceded December 31, 2001 as the last deadline to the bloc present a proposal to a gradual elimination of the AD and CVDs in intra-bloc trade, but it was not obeyed.

${ }^{34}$ Brazil only applied a minimum export price undertaking on imports of cement from Argentina and Uruguay in July 1991, to be abolished five years later in 1996. Moreover, Brazil also applied a minimum export price undertaking on imports of milk from Argentina and Uruguay in February 2001.

35 Piani (1998) shows that Brazil was also the preferential target for AD measures taken by Argentina from 1988 to 1994, with 12 out of 19 AD actions being imposed in Brazilian exports.

${ }^{36}$ Argentina also applied a safeguard measure on imports of cotton fabrics from Brazil in July 1999. This measure caused considerable concern about the future of the bloc as, in contrast to AD measures 
Table 5: Argentinean Anti-Dumping Actions Initiated and in Force by Country (1991-2000)

\begin{tabular}{|c|c|c|c|c|c|c|c|}
\hline Initiation & 1991-94 & 1995 & 1996 & 1997 & 1998 & 1999 & $2000-1^{/ 1}$ \\
\hline Brazil & 18 & 5 & 5 & 3 & 2 & 5 & 0 \\
\hline Paraguay & 1 & 0 & 0 & 1 & 0 & 0 & 0 \\
\hline Uruguay & 0 & 1 & 0 & 0 & 0 & 0 & 0 \\
\hline RoW & 24 & 14 & 14 & 8 & 4 & 10 & 5 \\
\hline Total & 43 & 20 & 19 & 12 & 6 & 15 & 5 \\
\hline Merc/Total/2 & $44.2 \%$ & $30.0 \%$ & $26.3 \%$ & $33.3 \%$ & $33.3 \%$ & $33.3 \%$ & $0.0 \%$ \\
\hline \multicolumn{8}{|l|}{ In Force ${ }^{3}$} \\
\hline Brazil & 13 & 10 & 10 & 12 & 12 & 12 & 11 \\
\hline Paraguay & 1 & 1 & 1 & 0 & 0 & 1 & 1 \\
\hline Uruguay & 0 & 0 & 0 & 0 & 0 & 0 & 0 \\
\hline RoW & 12 & 18 & 14 & 23 & 22 & 24 & 25 \\
\hline Total & 26 & 29 & 25 & 35 & 34 & 37 & 37 \\
\hline Merc/Total/4 & $53.8 \%$ & $37.9 \%$ & $44.0 \%$ & $34.3 \%$ & $35.3 \%$ & $35.1 \%$ & $32.4 \%$ \\
\hline
\end{tabular}

Despite allowing the use of AD and CVDs within the bloc, Mercosur has established common rules for both safeguards and AD actions against third countries in 1996 and 1997, respectively, giving power to the bloc to act on behalf of either a single member or the whole bloc. ${ }^{37}$ However, neither of these two norms were implemented by end 2000, leading all contingency measures that have been initiated and later applied on third countries imports since then by both Argentina and Brazil to be on an unilateral basis.

Although other PTAs, such as NAFTA and the Andean Pact, also allow the existence of contingency measures within the bloc this is not the general rule. In the EU, the European Free Association and Ancertza the use of these measures are not allowed in internal trade. More importantly, the imposition of $\mathrm{AD}$ actions in intrabloc trade is against the principle of the internal liberalisation behind the formation of a PTA and its allowance constitutes an important loophole in the integration process. Even though only Argentina has applied AD actions against other

that have been allowed by the bloc rulings, the application of safeguards was strictly prohibited from January 01, 1995 by the treaty of Asuncion. Thus, instead of being a loophole, Argentina's decision represented a clear breach of the bloc rules. However, nine months after its introduction, Argentina removed the safeguards, following the bloc ad hoc tribunal rulings in March 2000.

${ }^{37}$ The decisions $\mathrm{N}^{\circ} 17 / 96$ and $\mathrm{N}^{\circ}$ 11/97 laid down the common rules for safeguards and $\mathrm{AD}$ measures against third countries, respectively. 
partners and the share of its imports from within the bloc targeted by AD measures is small, the very presence of this sort of measures on internal trade may counteract the effectiveness of intra-bloc tariff elimination. As a result, they should be eliminated along with tariffs and any other form of non-tariff barriers. However, given the link between the removal of $\mathrm{AD}$ actions and the achievement of a common competition policy set up by the bloc, and the continuous delays in achieving the latter, it does not seem likely that the abolition of $\mathrm{AD}$ actions within the bloc will take place before 2006, well beyond the initial schedule of December 31, 2000. In the meantime, a plausible solution would be to follow the 'reverse dumping' clause established by the European Community during its transition period, where AD actions were allowed within the bloc. This clause stated that a dumped good could be re-imported into the exporting country duty-free, imposing an effective limit to dumping practices as far as the transaction costs are not too high.

\section{DEEPENING THE INTEGRATION}

Since the end of the transition period the attention of Mercosur has turned to issues related to deepening the scope of the integration process. Deep integration, as defined by Hoekman and Konan (1999:01), is constituted by "explicit actions by governments to reduce the market segmenting effect of domestic (non-border) regulatory policies through co-ordination and co-operation". The usual ways to address this issue are either harmonisation or mutual recognition of regulatory policies. Initially, Mercosur has sought to harmonise the bloc members national regulatory policies in areas such as technical regulations, phytosanitary measures, competition policy and government subsidies. However, due to proliferation of trade conflicts between the major partners of the bloc in issues related to phytosanitary and conformity assessment, there was a switch to mutual recognition of standards.

The first efforts to deepen the integration process sought to identify all NTBs in force in intra-bloc trade. Most of the 224 NTBs initially identified by the end of the transition period could be characterised either as technical barriers or sanitary and phytosanitary measures. ${ }^{38}$ The initial aim of the bloc in this matter was to eliminate the intra-regional barriers through harmonisation of technical regulations, sanitary and phytosanitary measures adopting the Mercosur norm. The formulation of Mercosur norms should be based on general principles and directives established on the "WTO's agreement on technical barriers to trade" and take into account, when appropriate, international, regional and sub-regional standards. ${ }^{39}$ With

\footnotetext{
${ }^{38}$ Decision $\mathrm{N}^{\mathrm{o}}$ 03/94.

${ }^{39}$ The bloc has been very active in developing common standards (Stephenson, 1997). By October 1999, Mercosur had established 274 standards, mostly in the steel sector, while there were 107 standards in final approval phase and another 687 were registered in the work plan (Martinez, 1999).
} 
respect to sanitary and phytosanitary measures, two major developments deserve to be pointed out. First is the agreement to carry out the inspections in the final destination instead of the frontier, in order to reduce costs and time involved in such procedures. ${ }^{40}$ Second is the adoption of the "WTO agreement on the application of sanitary and phytosanitary measures", which recommends WTO members to harmonise such measures based on international standards, guidelines and recommendations. ${ }^{41}$

Although some norms could be harmonised, by mid-1998 many products were still facing problems related to differences in conformity assessment and sanitary standards. Following the European Union example, which in some cases retreated back from its harmonisation ideal into mutual recognition solutions, Mercosur members pursued a more practical approach based on partial mutual recognition agreements, not necessarily including all four countries. ${ }^{42}$ The objectives were to negotiate agreements on equivalent sanitary and phytosanitary systems of control and mutual recognition agreements of conformity assessment. It was accomplished by the Resolution $\mathrm{N}^{\circ} 60 / 99$, which aimed to avoid unnecessary double controls, to eliminate physical controls at the frontier and to accelerate product circulation within the bloc. Based on those provisions the Argentinean and Brazilian national agencies started to form bilateral agreements on mutual recognition of conformity assessment in areas such electric and electronic products, toys, foodstuff and products related to health (IDB, 2000).

Despite the advances on this matter, Argentina and Brazil de facto continued to resort to technical barriers and phytosanitary measures to prevent imports from other members in the late 1990s. Argentina, once again, has been the most active member of the bloc in implementing those restrictive measures on imports from other regional partners. In 1999, all other members were targeted by at least one phytosanitary barrier. The other members, in contrast, have used these barriers on intraregional trade only sporadically and for a few products. The number of technical and phytosanitary barriers imposed by Argentina on Brazil's exports also grew significantly in 1999, as a result of the Brazilian exchange rate devaluation in January 1999. In March, a regime of pre-shipment inspection of most imported consumption goods was introduced. Labelling requirements on footwear and A4 paper were introduced in July and September, respectively. In both cases, the producers from Argentina and Brazil achieved an agreement establishing a VER. In August and October 2000, Uruguay and Argentina, respectively, applied a phytosanitary measure on Brazil's exports of pork. Brazil also

\footnotetext{
${ }^{40}$ Resolution $\mathrm{N}^{\circ}$ 60/94.

${ }^{41}$ Decision $\mathrm{N}^{\mathrm{o}} 06 / 96$.

${ }^{42}$ Resolution $\mathrm{N}^{\circ} 77 / 98$.
} 
restricted Argentina's exports of rice through phytosanitary measures in September $1999 .{ }^{43}$

Another issue that has been addressed by the bloc legislators is government procurement. By definition, the formation of a bloc should avoid discrimination in favour of domestic firms by national governments when procuring goods or services, since they often account for a significant share of GDP (World Bank, 2000). However, as also occurred with other deepening measures that have been dealt with since the end of the transition period, no agreement was in force by end 2000 . Nonetheless some efforts have been made in order to create common rules concerning this issue. Since the work did not advance properly an ad hoc group was created in order to help discipline the government procurement policies that distort competition. ${ }^{44}$

Although initially scheduled to deliver their recommendations in December 1998, the ad hoc group has not been able to finish its work since then, and the common regime has been continuously postponed. ${ }^{45}$

In summary, the ambitious plans covering a wide range of subjects belonging to the "deep agenda" have proved to be too ambitious. There are a number of factors that seem to have contributed to the delay in reaching the bloc initial goals concerning these issues. First, the macroeconomic instability that has hit the bloc members since 1995 has diverted the attention of the individual members from the bloc agenda, usually leading to national responses. Second, the recurrent delays in internalising the decisions adopted by the bloc bodies at the national level, since the Mercosur decisions have no direct effect in its members, seem to have played an important role in the failure to deepen the bloc integration. According to the Uruguayan government only half of the 1,024 norms approved by the bloc up to the end of 1999 were incorporated at the national legislation, which means that most of the other norms are not applicable yet (IDB, 2000). ${ }^{46}$ Third, some authors point out that Brazil has not been willing to deepen the integration process as the potential benefits from this are deemed to be smaller than the costs associated with the lost in sovereignty (e.g. Pereira, 1999; and Veiga, 1999). This evaluation is based on the idea that the asymmetry in size among the members markets would curtail the likely benefits of the bloc to Brazil.

\footnotetext{
${ }^{43}$ A survey made by the bloc identified 82 sanitary and phytosanitary measures in force within the bloc by mid- 2000 .

${ }^{44}$ Resolution $\mathrm{N}^{\mathrm{o}} 79 / 97$.

45 The Resolution $\mathrm{N}^{\circ} 81 / 99$ established a new deadline as June 30, 2000, which also was not accomplished.

${ }^{46}$ It is important to emphasise that some of the bloc decisions do not need to be internalised in any of the member states since they regulate aspects related to the bloc operation and organisation.
} 


\section{CONCLUSION}

The integration process followed by Mercosur members since 1991 has achieved important advances like the removal of intra-bloc tariff and non-tariff barriers and the establishment of a common external tariff for many products. However, macroeconomic instability caused by external crisis (Mexico-1994, South-East Asia-1997, Russia-1998) or domestic problems (Brazil's exchange rate devaluation-1999 and Argentina's possibility of default-2001), and interests of pressure groups have systematically diverted the bloc from achieving many of its goals in the agreed time-table. Events since 1995 have shown that whenever there has been a conflict between the national interest and the bloc rules, Mercosur members have invariably opted for either changing the rules of the game, negotiating with other members to postpone its application or adding more holes and loopholes to the agreement, or blocking the implementation of the bloc norms, not internalising them into the national legislation, since the bloc norms has no direct effect needing to be internalised by each member in their legal system.

In conclusion, after completing ten years of integration Mercosur has yet to achieve free trade area status. The allowance for tariffs in specific products such as sugar, managed trade in others, like automobiles, permission for intra-bloc $\mathrm{AD}$ duties and concessionary regimes have contributed to constrain trade between Mercosur members. The holes in the CET have raised the average and the range of national tariffs since 1995. The ambitious plans to deepen the integration process comprising harmonisation of policies in areas like competition policy, government procurement, technical barriers and phytosanitary measures have not been implemented yet, since they have not been negotiated yet or internalised at the national level due to the lack of direct effect. Thus comparing the bloc objectives with its achievements it could be said that it has done much ado but produced too little results.

\section{REFERENCES}

BHAGWATI, J. (1993), 'Regionalism and multilateralism: An overview', in J. de Melo and A. Panagariya (eds.), New Dimensions in Regional Integration, New York: Cambridge University Press, 22-51. ETHIER, W. (1998), 'The new regionalism', The Economic Journal, 449, 1149-1161.

FINGER, J. (1993), Antidumping: How it Works and Who Gets Hurt, Ann Harbor, Michigan: University of Michigan Press.

GROSSMAN, G. and E. HELPMAN (1995), 'The politics of free trade agreements', American Economic Review, 85, 667-690.

GUASCH, J. and S. RAJAPATIRANA (1998), 'Antidumping and competition policies in Latin America and Caribbean: Total strangers or soul mates?’, World Bank Working Papers, ${ }^{\circ} 243$, Washington DC, available at http://econ.worldbank.org/docs/243.pdf.

HOEKMAN, B. (1998), 'Free trade and deep integration: Antidumping and antitrust in Regional Trade Arrangements', World Bank Working Papers, $\mathrm{n}^{\circ}$ 1950, Washington DC, available at http://econ. worldbank.org/docs/749.pdf. 
HOEKMAN, B. and D. KONAN (1999), 'Deep integration, non-discrimination, and Euro-Mediterranean free trade', World Bank Working Papers, ${ }^{\circ}$ 2130, Washington DC, available at http://econ. worldbank.org/docs/532.pdf.

HOEKMAN, B. and M. KOSTECKI (1995), The Political Economy of the World Trading System, New York: Oxford University Press.

HOEKMAN, B. and M. LEIDY (1993), 'Holes and loopholes in the integration agreements: History and prospects', in K. Anderson and R. Blackhurst (eds.), Regional Integration and the Global Trading System, London: Harvester-Wheatsheaf, 218-245.

IDB - Inter-American Development Bank (1996), Mercosur Report, $n^{\circ}$ 1, Buenos Aires, available at http://www.iadb.org/intal/.

IDB - Inter-American Development Bank (2000), Mercosur Report, $n^{\circ}$ 6, Buenos Aires, available at http://www.iadb.org/intal/.

KRUEGER, A. (1997), 'Free trade agreements versus custom unions', Journal of Development Economics, 54, 169-187.

LAWRENCE, R. (1997), 'Preferential trading arrangements: The traditional and the new', in A. Galal and B. Hoekman (eds.), Regional Partners in Global Markets, CEPR, Egypt: The Egyptian Center for Economic Studies, World Trade Center, 13-34.

MARTINEZ, I. (1999), 'Brazil: Standards and regulations', Trade Report, available at http://www. tradeport.org/ts/countries/brazil/mrr/mark0055.html.

OLARREAGA, M. and I. SOLOAGA (1998), 'Endogenous tariff formation: The case of Mercosur', World Bank Economic Review, 12, 297-320.

OLARREAGA, M., I. SOLOAGA and L. A. WINTERS (1999), 'What's Behind Mercosur's Common External Tariff?', Policy Research Working Paper, n 2231, Washington DC: World Bank.

PEREIRA, L. (1999), 'Toward the common market of the South: Mercosur's origins, evolution, and challenges', in R. Roett (ed.), Mercosur: Regional Integration, World Markets, London: Lynne Rienner, 7-23.

PIANI, G. (1998), 'Medidas antidumping, anti-subsídios e de salvaguardas: Experiência recente e perspectivas no Mercosul', IPEA Discussion Paper, n 541, Brasília, DF: IPEA, available at http:// www.ipea.gov.br/pub/td/td0541.pdf.

PREUSSE, H. (2001), 'Mercosur - Another failed move towards regional integration?, World Economy, 24, 911-931.

STEPHENSON, S. (1997), 'Standards, conformity assessment and developing countries', World Bank Working Papers, $n^{\circ}$ 1826, Washington DC, available at http://econ.worldbank.org/docs/398.pdf.

VEIGA, P. (1999), 'Brazil in Mercosur: Reciprocal influence', in R. Roett (ed.), Mercosur: Regional Integration, World Markets, London: Lynne Rienner, 25-33.

World Bank (2000), Trade Blocs, Washington: Oxford University Press.

WTO - World Trade Organization (1996), 'Trade Policy Review: Brazil', Geneva, available at http:/l www.wto.org/english/tratop_e/tpr_e/tp45_e.htm.

WTO - World Trade Organization (1997), 'Trade Policy Review: Paraguay', Geneva, available at http:// www.wto.org/english/tratop_e/tpr_e/tp57_e.htm.

WTO - World Trade Organization (1998a), ‘Trade Policy Review: Uruguay', Geneva, available at http://www.wto.org/english/tratop_e/tpr_e/tp91_e.htm.

WTO - World Trade Organization (1998b), 'Trade Policy Review: Argentina', Geneva, available at http://www.wto.org/english/tratop_e/tpr_e/tp100_e.htm. 